\title{
ETHICAL CREDIBILITY RISKS MONITORING IN MANUFACTURING COMPANIES IN SLOVAKIA AND V4 COUNTRIES
}

\author{
Erika SUJOVÁ, Helena ČIERNA, Jaroslava ŠTEFKOVÁ \\ Technical University in Zvolen
}

\begin{abstract}
:
Among the significant determinants influencing the corporate culture is the degree of riskiness in the operational activities of a company. Firstly and most importantly, business entities must be prepared to respond quickly to the needs of an external as well as the internal environment, to be in close relationship with customers, to use internal business activities, to strive to build the desired way of behaviour and actions of all stakeholders. The paper aims to define possible risks of ethical credibility based on the analysis and research in selected production companies operating in Slovakia and then propose options, measures to eliminate the threats to ethical credibility and thus increase the credibility and reliability of manufacturing companies.
\end{abstract}

Key words: ethical credibility, risks, corporate culture, ethics, manufacturing companies

\section{INTRODUCTION}

The qualitative social changes that have occurred in the new millennium are characterized primarily by globalization and multiculturalism, and by the internationalization of economic processes. These changes are also requesting a new approach to the formation of non-traditional business approaches, which should enable businesses to improve their economic results and provide them with a competitive advantage. Corporate culture, as the bearer of ethical and moral norms and principles, enters this process as an indisputable factor in the success of the company acquiring a global platform [2].

Business venturing and competition are activities that are performed, managed and their results are used in the form of products and services by consumers. There are different relationships between the consumer and the producer, the consumer and the entrepreneur, and the entrepreneurs reciprocally $[1,8]$. Good relationships need to provide feedback. Just as they cannot be crammed into strictly linked bonds, each individual cannot be programmed into a chess piece, yet, they cannot be left out. It can be concluded that in addition to the explicitly economic side of the business, i.e., profit-oriented, there is something else related to the long-term orientation of the success of an entrepreneur, a company, and that is ethics as a part of the business $[15,20]$.

Business ethics is the study of what constitutes the right and the wrong, the good or the bad in human behaviour in the context of business. The study of business ethics is a part of a broader, general study of ethics, based on primary ethical concepts, concepts, and theories seeking to identify criteria for the correct and incorrect conduct of individuals and organized structures in society $[13,26]$. We believe that business ethics in practice takes place at four levels, which are the global, social, organizational, and individual levels. This breakdown is crucial in the utilization of business ethics in practice, as it points out that the employment of ethics to the economy is the responsibility of various entities by many works [14, 31, 32].

Ethics and its observance in management can contribute to building trust and increasing the level of interpersonal relationships. It thus has its share in the performance of competitiveness and the overall results. At the same time, it acts as a regulator of the tension between the different economic and social interests of business entities and society. Businesses cannot dictate their values to society, but they must respect the values of society [6].

The subject of the article is the monitoring of the risks of ethical credibility of manufacturing companies with a focus on engineering in the V4 countries. The term ethical credibility refers to the credibility and reliability of people in a company in terms of their behaviour. Creating an environment of trustworthiness and reliability allows companies to assert themselves better in the social image, and all actors who strive to do so are more likely to be recognized and accepted in the market. However, some companies do not have appropriate ethics in place, which can 
lead to many risks. Ethical credibility is crucial in companies. Without it, businesses would not be able to function and prosper. The main goal of our research is to design a procedure or measures to minimize the risks of ethical credibility in the analysed manufacturing companies. The article is part of the solution of the research project APPV -17-0400 project „Enhancing the Ethical Environment in Slovakia (Institutional Procedures, Actors, Risks, and Strategies).

\section{LITERATURE REVIEW}

Ethical credibility is based on ethical values, which can also be called ethical principles. The ethical principles incorporate the characteristics and values that most people associate with ethical behaviour. We can state that corporate culture and its ethical values are directly determined through the behaviour and actions of managers who are to lead by their example. Corporate culture, as a bearer of ethical and moral norms and principles, comes to the fore as an indisputable factor in the success of a company in the competitive struggle, which acquires a global platform $[9,14]$. The degree of riskiness of the subject of business strongly determines the corporate culture. The degree of riskiness in a business means the intensity of the threat to the further prosperity of the company by one failure in one of the other activities of the company as is presented in many works $[6,17]$.

Building the credibility of any entity allows it to assert itself better in the more complex social environment. All actors working to build credibility are aware that credibility means being accepted, recognized, and preferred. It is also a recognition of the customer, the citizen, stakeholders, the public interest, and social well-being [10, 20, 32]. We believe that any form of credibility creation can make sense if it is driven by an ethical intent. It is also important that it be supported not only by individual ethical ambition but as a systemic form of ethical support.

Meslin et al. [24] examined the relationships between industrial and university researchers. Based on the research results, they identified final list included nine principles of ethical credibility concerning the active development and encouragement of AHC-industry research partnerships (AHCIP), which are: Academic freedom, Conflict of interest policy and management, Data sharing and access, Intellectual property, Effective governance, Protection of human subjects, Publication, Transparency; Social, scientific, and Industrial value $[11,22,28]$. In connection with the last principle, they stated that partnerships that parties benefit from should be involved by satisfying the particular goals of each partner. An ethically credible partnership should seek to create value that, overall, will contribute to others. An ethically credible partnership will also be cognizant of the competitive nature of industry and academia and will seek to maintain reasonably any competitive advantage or expertise a partner might have in each area of research $[4,5,16]$.

Organizational ethics includes a professional ethical approach, such as the systematic introduction of ethics into the organizational environment in companies should be based on considered and sensitively developed ethical programs. They stated the significant contribution of an ethical program in preventing unethical behaviour and creating a positive reputation combined with credibility and goodwill. Experts [10, 11, 31] wrote about organizational, ethical, and economic integrity. According to him, it is the ethical view contra the economic view: a virtue or a workability concept of integrity. Here we confront the ethical view with the economic view of integrity.

Petrovic [25] deals with the relationship between scientific knowledge and ethical credibility. Her research states the importance of linking scientific, namely social, research with ethical statutes. The result of the research is the finding that a growing number of scientific institutions are trying to protect their academic credibility from compromises by aligning their research with ethical rules through the issuance of codes. The study of Lee [19] examines consumers' uses of corporate social responsibility (CSR) communication channels, the relationship of such uses to consumers' CSR awareness. They also explored the mediation effects of consumers' CSR associations with a company, consumers' assessment of the company's CSR credibility, and consumers' perceptions of their relationship with the company, which is also a question of ethical approach.

Lafferty et al. [18] published the research in which they propose a model of the combined impact of the credibility of companies and their customers. The results of several studies $[2,21,28]$ have confirmed that the dual trust model partially predicts and explains the effectiveness of advertising for these dual sources of trust. Several studies $[2,7,22]$ were published on the scope of the importance of ethical credibility in business. Ethical credibility today is stated to be a significant factor of economic prestige and business success. Professional assistance in creating the policy of ethics is considered an important part of building the institution's credibility and good reputation. The terms credibility and reputation are used as synonyms there. According to Balúnová [3] and Simanová and Gejdoš [29], the degree of credibility depends on the extent to which the company can deal with matters beyond its control - external events, competitor failure, or poor supply chain management.

We expect that all these factors harm the value of management's reputation and perception. The conclusions of the published studies state that credibility may be managed with some ethical tools and in a professional way. These procedures depend on the organisation's management whether it is perceived as an active part of its policy or whether is only seen as a secondary and unimportant medium. The results of various research have proved that businesses need to pay due attention to building a reputation for credibility to be successful.

\section{METHODOLOGY}

The main focus of the article is to identify and analyse the risks of ethical credibility in the manufacturing companies of the eastern European countries of the Community V4. An online questionnaire was created for the research, which was distributed to selected companies via the Internet [23]. 
For the questionnaire, two research hypotheses were stated:

- H1: The term of ethical credibility is unknown to the manufacturing companies.

- $\mathrm{H} 2$ : The manufacturing companies have identified the process risks.

\section{QUESTIONNAIRE TO ASSESS THE ETHICAL CREDIBILITY RISKS}

A questionnaire is a research tool that makes it possible to obtain data quickly and easily from a large number of respondents. For our research, the online questionnaire was a suitable research method. Great attention was paid to the formulation of questions to obtain relevant answers. At the beginning of the creation of the questionnaire, the principal evaluation criteria and questions leading to information about manufacturing companies - survey respondents - were determined. In the structure of the questionnaire, the first four questions were designed to anonymously find out information about the participating respondents (companies): 1 . Country of establishment, 2 . The number of employees of the company, 3 . The focus of the company, 4. Percentage of women in the company.

According to the number of employees, enterprises were divided into micro-enterprises (up to 9 employees), small enterprises (10 to 49 employees), medium-sized enterprises (50 to 249 employees), and large enterprises (250 and more employees). In the second step, the companies and the focus which will be part of our analysis were determined. We selected three main areas of technology: manufacture of machinery and equipment; production and processing of metals; production and processing of wood.

In the research part of the questionnaire, six questions were formulated for the evaluation of the ethical credibility of companies. The following parameters were evaluated in the research:

1. Introduction of a code of ethics in the company.

2. Observance of ethical principles.

3. The existence of competent employees in the company to solve problems, opinions, and suggestions of employees.

4. Introduction of a quality management system.

5. The existence of a process risk assessment system.

6. Ways to inform employees about identified risks.

The research questions were supplemented in the questionnaire by the possibility of open answers, where we asked respondents about the implementation of the area, the specific ethical risks, or the most common risks [23]. The electronic online questionnaire was created in the MS Office 365 Forms application. The procedure for the dissemination of the questionnaire consisted of a selection of the companies within the scope of the research via the ec.europa.eu database, sending a link to the questionnaire to the company's contact e-mail from the database. The questionnaire was sent to $\mathbf{4 3 0}$ manufacturing companies operating in the V4 countries. The response time was set at four weeks. 132 responses returned within the set time, i.e., the return rate of the questionnaire was $30.7 \%$.

\section{RESULTS ANALYSIS}

Based on the analysis of the results of the questionnaire survey, the following data were retrieved from respondents:

1. The country of the company's official seat: Slovakia 119 companies, the Czech Republic - 8; Poland - 3, Hungary -2.

2. Company's size: micro-enterprises - 3, small enterprises - 50, medium-sized enterprises - 67 and large enterprises -12 .

3. Enterprises by industry focus: manufacture of machinery and equipment -31 , manufacture and processing of metals -72 , manufacture and processing of wood 29.

4. The average representation of women in the analysed manufacturing enterprises is $11.3 \%$.

From the point of view of research goals focused on business ethics, the principal question was whether a company has a code of ethics. Another question is if a company does not have a code of ethics, what ethical rules it follows. There were three evaluation categories in the questionnaire:

1. A company that has a code of ethics.

2. A company that does not have a code of ethics and rules of ethical conduct are not addressed in company directives.

3. The rules of ethical conduct are incorporated in general guidelines.

The existence of the code of ethics based on the mentioned categories is shown in Fig. 1 . The results of the analysis show that the vast majority, up to $62 \%$, are companies that do not have a code of ethics and do not address the rules of ethical conduct in any company directive. In terms of the ethical credibility of manufacturing companies in the field of metal production and processing, $43 \%$ of this category of companies have a code of ethics or general regulations and $57 \%$ of the companies state that they work on ethical principles without mentioning them in company documents. As for manufacturing companies in wood production and processing, 33\% have a code of ethics in place. For companies in machinery and equipment, 33\% have an established code of ethics, and $66 \%$ think they work based on ethical principles even without their incorporation in company documents.

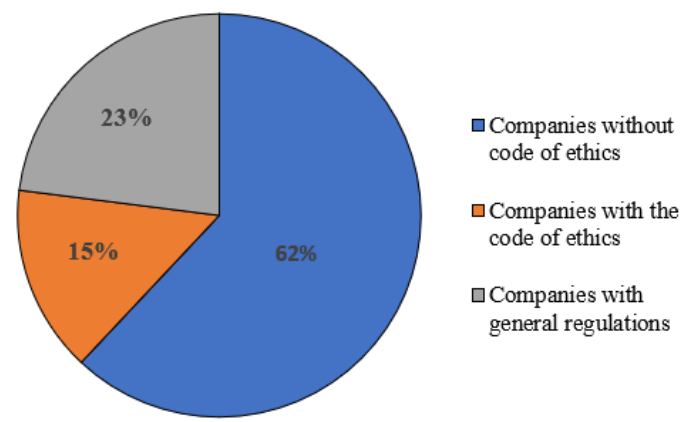

Fig. 1 The existence of ethical codes in the companies 
When evaluating the ethical credibility of manufacturing companies (respondents) working in the machinery and equipment field, $33 \%$ of companies operating in the V4 countries have a code of ethics in place and $66 \%$ work on ethical principles without a stated code of conduct. All respondents declare that they have people to solve the problems of employees. Manufacturing companies operating in the metal production and processing area stated that $43 \%$ have a code of ethics in place, or general regulations in ethics, $57 \%$ of companies work based on ethical principles. $71 \%$ of the respondents have identified process risks, and this percentage has a range of employees to solve problems and collect employees' opinions and suggestions. Manufacturing companies working in the wood production and processing area stated that 33\% have a code of ethics in place; all respondents state that they work under ethical principles, but they also do not have employees who would solve problems, suggestions, and opinions of employees.

\section{DISCUSSION}

In terms of evaluating the research part of the questionnaire, the existence of a code of ethics in companies was evaluated (showed above), and we also found out the respondents' opinions on whether they think their company works on ethical principles, even if it is not stated in internal documents. Roughly $30.3 \%$ of the total number claim that their company does not work on ethical principles, where a considerably high number is bearing a supposedly negative impact. In the next analysis, specific ethical principles which companies recognized in the company were investigated. Respondents could indicate more options. The results of the analyses are shown in the bar graph in Fig. 2.

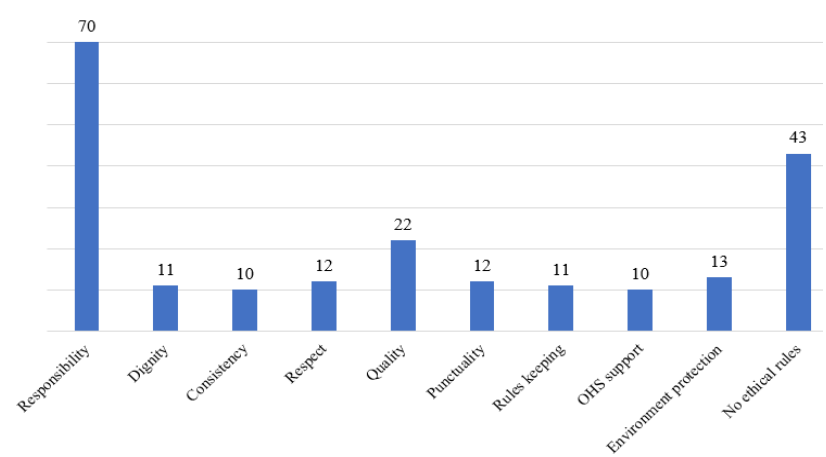

Fig. 2 Ethical codes recognized in the companies

In terms of the functioning and management of interpersonal relationships, the person whom company employees can turn to in case of solving their problems, or to whom they can communicate opinions and suggestions was another investigated category. The research results are illustrated as percentages in the pie chart shown in Fig. 3.

From the results shown in Fig. 3, it is clear that up to $31 \%$ of employees do not communicate their problems and suggestions with other colleagues because they do not seem to have anyone in the company to turn to. Employ- ees' representatives are the most represented in the number of communicating colleagues (23\%), followed by direct managers, supervisors (foremen) of centres (15\%), and then discussions among colleagues (15\%).

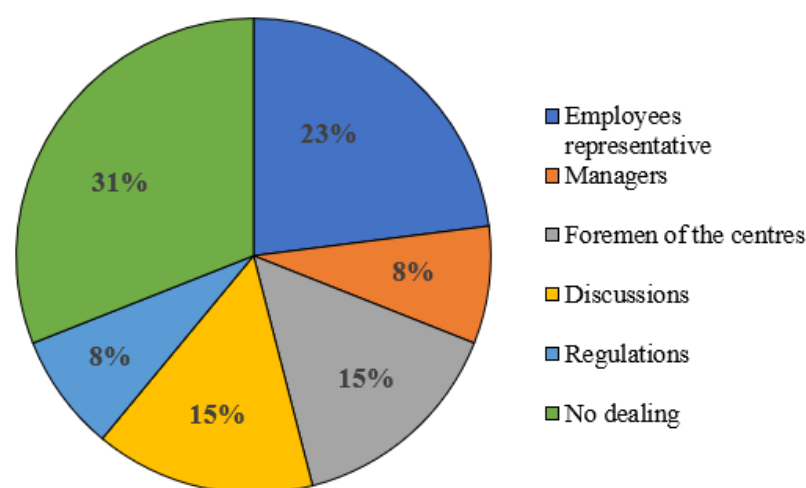

Fig. 3 Representation of the personnel to communicate the ethical issues

The next part of the research concerned risk assessment and risk awareness. In Fig. 4 are the percentages of the answers to the method of identifying process risks in companies. The results show that the risks are most often assessed within the framework of health and safety directives. Astonishingly, up to $31 \%$ of companies state that they do not have identified risks, or respondents are not informed of this fact.

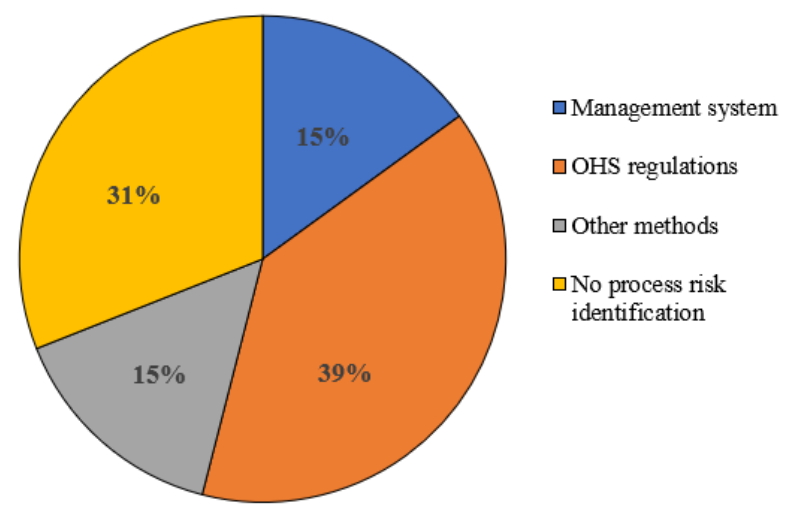

Fig. 4 Process risk identification

Concerning awareness of process risks (Fig. 5), the most common communication channel was managers accounting for 68 responses, followed by information boards and health and safety (more than 40 responses). Respondents could choose more than one option.

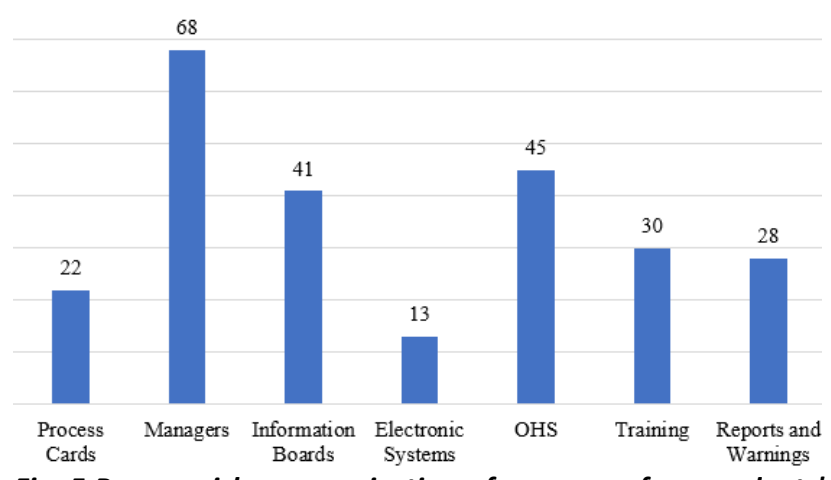

Fig. 5 Process risk communication - frequency of respondents' answers 
In terms of ethical credibility, important parameters for our research were the code of ethics, ethical principles, problem-solving, opinions and suggestions of employees, and, last but not least, process management, identification of process risks, and informing employees about possible risks.

\section{PROPOSAL OF A PROCEDURE FOR IMPLEMENTATION AND STRENGTHENING THE ETHICAL ENVIRONMENT IN COMPANIES}

Based on the results of our research of manufacturing companies operating in the V4 countries, the method to increase the reliability and credibility of companies is suggested. The design of the algorithm of implementation steps (Fig. 6) is proposed to strengthen the ethical environment in companies.

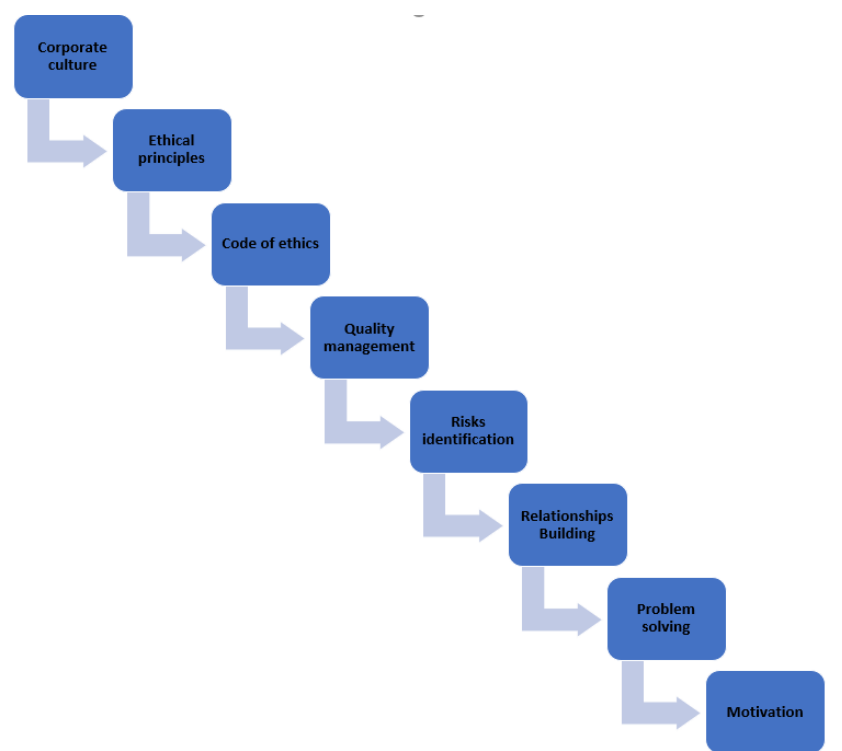

Fig. 6 Design of an algorithm for implementation steps of the ethical environment

Every company has gradually formed its unique corporate culture since the beginning of its existence. A well-created corporate culture has defined generally valid regulations, orders, and wishes, which show or prohibit specific activities in the company. Symbols are an important parameter of the corporate culture. Symbolic behaviour is expressed in the form of rituals, customs, ceremonies that take place in the company.

\section{CONCLUSIONS}

In the research, the parameters of ethical credibility were analysed. The parameters of ethical credibility are code of ethics, ethical principles, problem-solving, opinions and suggestions of employees, quality management system, identification of process risks, and informing employees about possible risks. The quality management system can include production processes, manufactured products, and their quality, resource management, relations between suppliers and customers, risk management, meeting customers' requirements, and customers' satisfaction. The common parameters of ethical credibility and quality management are the processes risks that need to be addressed constantly and minimized or removed.

As the results of our research and the overall summary of respondents' answers show, only 28 manufacturing companies have all important parameters of ethical credibility in place, which can be described as their high reliability and credibility; however, considering the total number of respondents it is a low proportion. After evaluating hypothesis $\mathrm{H} 1$, it can be stated that the term of ethical credibility is not unknown to the manufacturing companies. Resulting from the research findings it was found that only $15 \%$ of the organisations devote appropriate attention to ethical credibility. The evaluation of hypothesis $\mathrm{H} 2$ confirmed that two-thirds (2/3) of the analysed companies had identified the process risks. However, there is also a striking finding that $31 \%$ of the companies had not identified the process risks, even though, it is a necessary requirement of ISO 9001:2015 standard.

Every company has gradually formed its unique corporate culture since the beginning of its existence. A well-created corporate culture has defined generally valid regulations, orders, and wishes, which show or prohibit specific activities in the company. Symbols are a significant parameter of the corporate culture. Symbolic behaviour is expressed in the form of rituals, customs, ceremonies that take place in the company.

To improve stability, development, and interpersonal relationships, the company should work based on ethical principles. From an ethical point of view, the critical principles are respect, dignity, uniqueness, responsibility, and solidarity. A company that works based on at least two of these principles significantly increases its credibility with customers. The code of ethics is part of the corporate culture. It serves as a tool for people management and should not be missing in the management strategy.

The identification of process risks aims at addressing the risks and the extent to which the production process is exposed. The optimal way to identify and subsequently reduce risks is to create so-called process cards.

Every company should have an employee in charge of solving ethical problems in the workplace or the company. It may be an employee who will only deal with ethical issues, or it may be an employee from some management positions who will be familiar with the process of dealing with adverse situations arising in the workplace or the company.

The introduction of our proposed algorithm of steps in manufacturing companies will strengthen the ethical environment so that the company will have clearly defined rules and principles. Employees will be informed of changes and regulations that are implemented in individual workplaces. Such employees will be better able to adhere to work ethic, minimize problems and breaches of ethical principles in a company, and make it easier to deal with adverse situations. The introduction of the mentioned algorithm can also eliminate the risks of selected processes in manufacturing companies. 


\section{ACKNOWLEDGEMENT}

The author would like to acknowledge the Agency APPV for their support of the APPV-17-0400 project „Enhancing the Ethical Environment in Slovakia (Institutional Procedures, Actors, Risks, Strategies) ". This article was created as a part of the project.

This publication is the result of the project implementation: „Progressive Research into Utility Properties of Materials and Products Based on Wood (LignoPro), ITMS $313011 T 720$ supported by the Operational Programme Integrated Infrastructure (OPII) funded by the ERDF."

\section{REFERENCES}

[1] Alcañiz, E.B., Cáceres, R.C. \& Pérez, R.C. “Alliances Between Brands and Social Causes: The Influence of Company Credibility on Social Responsibility Image". J Bus Ethics 96, pp. 169-186 (2010). https://doi.org/10.1007/s10551-010-0461-x

[2] Annas, J. "Virtue ethics". Copp D. (Ed.) The Oxford Handbook of Ethical Theory. Oxford: Oxford University Press, pp. 515-536

[3] Balúnová, Z. "The importance of ethical credibility in business". In Zeszyty naukowe Politechniki Ślqskiej 2016. Seria: Organizacja i Zarządzanie z. $94 \mathrm{Nr}$ kol. 1958.

[4] Carpenter W.T. Jr, Koenig J.I., Bilbe G., Bischoff S. "At issue: a model for academic/industry collaboration." Schizophr Bull 30:997

[5] Clackson T. "Translational research in academia and industry". Exp Biol Med. 231:1685-1689

[6] Čierna, H., Sujová, E. and M. Ťavodová. "Selected aspects of management for technicians". Zvolen: TU Zvolen, FEVT, 2015. ISBN 978-80-228-2733-1

[7] Emanuel E.J., Wendler D., Killen J., Grady C. "What makes clinical research in developing countries ethical? The benchmarks of ethical research". J Infect Dis 189:930-937

[8] Erdem, T., Swait, J., \& Louviere, J. "The impact of brand credibility on consumer price sensitivity". International Journal of Research in Marketing, 19, pp. 1-19. https://doi.org/10.1016/S0167-8116(01)00048-9

[9] Fobel, P. Proceedings of scientific papers from the workshop of young science "Soft competencies and creation of value environment in Slovakia". Belianum UMB Banská Bystrica. 2019. p. 77. ISBN 978-80-557-1576-6.

[10] Fobel, P. et al. "Organizational ethics and professional ethical advice". Scientific monograph. APRINT, s.r.o. Žiar nad Hronom. 2013. P. 215. ISNB 978-80-89415-11-3.

[11] Hąbek, P., Biały, W. and G. Livenskaya. "Stakeholder engagement in corporate social responsibility reporting. The case of mining companies", in Acta Montanistica Slovaca. 2019, vol. 24, no. 1, pp. 25-34.

[12] Hąbek, P. and Lavios, J. J. "Analysis of Sustainable Production Practices Implemented by Car Manufacturers 2018". In Multidisciplinary Aspects of Production Engineering MAPE vol. 1, iss. 1, 201, 8. (2018). DOI: 10.2478/mape2018-0105.

[13] Hovland, C. I., \& Weiss, W. "The influence of source credibility on communication effectiveness". Public Opinion Quarterly 15(4), 2010. pp. 635-650.

[14] Hur, W.M., Kim, H. \& Woo, J. "How CSR Leads to Corporate Brand Equity: Mediating Mechanisms of Corporate Brand Credibility and Reputation". J Bus Ethics 125, pp. 75-86 (2014). https://doi.org/10.1007/s10551-013-1910-0.
[15] Inoue, Y., Kent, A. "A Conceptual Framework for Understanding the Effects of Corporate Social Marketing on Consumer Behavior". J Bus Ethics 121, pp. 621-633 (2014). https://doi.org/10.1007/s10551-013-1742-y

[16] Johns M.E., Barnes M., Florencio P.S. "Restoring balance to industry-academia relationships in an era of institutional financial conflicts of interest: promoting research while maintaining trust". JAMA 289:741-746. Josephson Institute, 2010. Available: https://josephsononbusinessethics.com/2010/12/12-ethical-principles-for-business-executives/

[17] Kim, S. "Transferring Effects of CSR Strategy on Consumer Responses: The Synergistic Model of Corporate Communication Strategy", Journal of Public Relations Research, 23:2, pp. 218-241, DOI: 10.1080/1062726X.2011.555647

[18] Lafferty, B. A., Goldsmith, R. E., \& Newell, S. J. "The dual credibility model: The influence of corporate and endorser credibility on attitudes and purchase intentions". Journal of Marketing Theory and Practice, Volume 10, 2002, Issue 3, pp. 1-11. Available: https://doi.org/10.1080/10696679.2002.11501916

[19] Lee, S.Y., Zhang, W. \& Abitbol, A. “What Makes CSR Communication Lead to CSR Participation? Testing the Mediating Effects of CSR Associations, CSR Credibility, and Organization-Public Relationships". J Bus Ethics 157, pp. 413-429 (2019). https://doi.org/10.1007/s10551-017-3609-0

[20] McWilliams, A., Siegel, D. S., \& Wright, P. M. "Corporate social responsibility: Strategic implications." Journal of Management Studies, 43, pp. 1-18. 2006. https://doi.org/10.1111/j.1467-6486.2006.00580.x

[21] Newell, S. J., \& Goldsmith, R. E. "The development of a scale to measure perceived corporate credibility". Journal of Business Research, 52(3), 235-247., ISSN 0148-2963, https://doi.org/10.1016/S0148-2963(99)00104-6.

[22] Kuzior, A. "Rola CSR w działalności "zrównoważonego przedsiębiorstwa". Business innovation - źródła przewagi konkurencyjnej, red. Piotr Bartkowiak, Robert Kucęba. Toruń : Towarzystwo Naukowe Organizacji i Kierownictwa Stowarzyszenie Wyższej Użyteczności "Dom Organizatora, s. 307-322.

[23] Mancel, V. "Risks of ethical credibility of selected manufacturing companies in Slovakia." Diploma thesis. TU Zvolen, Faculty of Technology. 2021. $67 \mathrm{p}$.

[24] Meslin, E. M. et al. "Benchmarks for ethically credible partnerships between industry and academic health centers: beyond disclosure of financial conflicts of interest." Clinical and Translational Medicine. 2015. 4:36. DOI 10.1186/s40169-015-0077-y.

[25] Petrovic, R. "Ethical credibility of scientists in social research". Research in Pedagogy, Vol. 7, Issue. 2017. pp. 98105. DOI: $10.17810 / 2015.52$.

[26] Prabu D., Kline S. \& Dai Y. “Corporate Social Responsibility Practices, Corporate Identity, and Purchase Intention: A Dual-Process Model." Journal of Public Relations Research, 17:3, pp. 291-313, $2005 . \quad$ DOI: 10.1207/s1532754xjprr1703_4

[27] Rendtorff, J. D. "Handbook of Research on Teaching Ethics in Business and Management Education; Chapter: Business Ethics, Strategy and Organizational Integrity: The Importance of Integrity as a Basic Principle of Business Ethics That Contributes to Better Economic Performance." 2012. DOI: 10.4018/978-1-61350-510-6.ch016.

[28] Sego, T. "When brands and social issues are linked: The relationship between company credibility, company liking, and issues intentions." American Marketing Association Conference Proceedings, 2002. 13, 171. 
[29] Simanová, L'. and P. Gejdoš. "Application of selected methods and approaches for improvement of processes and their use in practice in companies of wood processing industry in Slovakia", in Management Systems in Production Engineering, vol. 27, no. 3,. pp. 162-165, 2019.

[30] Taylor R.B. "Ethics, Credibility, and Trust." In: Medical Wisdom and Doctoring. Springer, New York, NY. 2010. https://doi.org/10.1007/978-1-4419-5521-0_12.
[31] Wankel, C., \& Stachowicz-Stanusch, A. "Handbook of Research on Teaching Ethics in Business and Management Education". 2012. IGI Global. http://doi:10.4018/978-161350-510-6

[32] Walker, M., Kent, A. "The Roles of Credibility and Social Consciousness in the Corporate Philanthropy-Consumer Behavior Relationship". J Bus Ethics 116, 341-353 (2013). https://doi.org/10.1007/s10551-012-1472-6

\section{Erika Sujová}

ORCID ID: 0000-0003-4281-4830

Technical University in Zvolen

Faculty of Technology

Department of Manufacturing Technology and Quality Management Študentská 26, Zvolen, 960 01, Slovak Republic

e-mail: erika.sujova@tuzvo.sk

\section{Helena Čierna}

ORCID ID: 0000-0003-2084-9282

Technical University in Zvolen

Faculty of Technology

Department of Manufacturing Technology and Quality Management

Študentská 26, Zvolen, 960 01, Slovak Republic

e-mail: helena.cierna@tuzvo.sk

\section{Jaroslava Štefková}

ORCID ID: 0000-0001-6500-2558

Technical University in Zvolen

The Institute of Foreign Languages

T.G. Masaryka 24, Zvolen, 960 01, Slovak Republic

e-mail: stefkova@tuzvo.sk 